\title{
OCCUPATIONAL EXPOSURE TO BISPHENOL A (BPA) IN A PLASTIC INJECTION MOLDING FACTORY IN MALAYSIA
}

\author{
WIDED KOUIDHI ${ }^{1}$, LETCHUMI THANNIMALAY ${ }^{2}$, CHEN SAU SOON ${ }^{2}$, and MUSTAFA ALI MOHD ${ }^{1}$ \\ ${ }^{1}$ University of Malaya, Kuala Lumpur, Malaysia \\ Department of Pharmacology Faculty of Medicine \\ ${ }^{2}$ SIRIM: Scientific and Industrial Research Institute of Malaysia, Selangor Darul Ehsan, Malaysia \\ Environment and Bioprocess Technology Centre
}

\begin{abstract}
Objectives: The purpose of this study has been to assess ambient bisphenol A (BPA) levels in workplaces and urine levels of workers and to establish a BPA database for different populations in Malaysia. Material and Methods: Urine samples were collected from plastic factory workers and from control subjects after their shift. Air samples were collected using gas analyzers from 5 sampling positions in the injection molding unit work area and from ambient air. The level of BPA in airborne and urine samples was quantified by the gas chromatography mass spectrometry - selected ion monitoring (GCMS-SIM) analysis. Results: Bisphenol A was detected in the median range of $8-28.3 \mathrm{ng} / \mathrm{m}^{3}$ and $2.4-3.59 \mathrm{ng} / \mathrm{m}^{3}$ for the 5 sampling points in the plastic molding factory and in the ambient air respectively. The median urinary BPA concentration was significantly higher in the workers $(3.81 \mathrm{ng} / \mathrm{ml})$ than in control subjects $(0.73 \mathrm{ng} / \mathrm{ml})$. The urinary BPA concentration was significantly associated with airborne BPA levels $(\varrho=0.55, \mathrm{p}<0.01)$. Conclusions: Our findings provide the first evidence that workers in a molding factory in Malaysia are occupationally exposed to BPA. Int J Occup Med Environ Health 2017;30(5):743-750
\end{abstract}

Key words:

Occupational exposure, BPA, Plastic factory, Environmental exposures, Malaysian workers, Molding process

\section{INTRODUCTION}

The plastic industry is a standout amongst the most dynamic areas in Malaysia. Malaysia plastic industry has built up a much expanded sector delivering a variety of items including car segments, electrical and gadgets parts, components for the media transmission industry, development materials, housewares items, bundling materials and toys.

The main production processes involved in the plastic industry in Malaysia include the injection molding of polycarbonates [1]. Polycarbonate is a polymer made out of numerous identical units of bisphenol A associated via carbonate-linkages in its main chain. The injection molding process consists of transforming the polycarbonate into the required shape by softening it and injecting it under pressure to fill in a mold. Bisphenol A (BPA), is a well-known endocrine disruptor, and is one of the most produced chemical in the world. Approximatively 8 billion pounds is delivered every year and

Funding: this study was conducted in the Shimadzu-UMMC Centre for Xenobiotics Study (SUCXeS). The funding was provided by the High Impact Research Grant (UM.C/625/1/HIR/MOHE/MED/07) from the Ministry of Higher Education Malaysia. Project supervisor: Prof. Mustafa Ali Mohd.

Received: February 4, 2016. Accepted: August 11, 2016.

Corresponding author: W. Kouidhi, University of Malaya, Department of Pharmacology Faculty of Medicine, Jalan university, 50603 Kuala Lumpur, Malaysia (e-mail: wided.kouidhi@gmail.com). 
around $100 \mathrm{t}$ discharged into the air each year [2]. In AsiaPacific district, BPA is more often used in the production of polycarbonate plastics (60-70\%) than epoxy resins.

It has been shown that BPA has estrogenic properties in vitro and in vivo. In fact BPA is able to interact with the estrogen receptor (ER), and may likewise bind many other hormone receptors such as androgen receptor, thyroid hormone receptor, peroxisome proliferator actuated receptor- $\gamma$ (PPAR) [3].

In humans BPA is associated with adverse effects on testis and pituitary gland [4], abnormalities [5], social impairment [6], a risk for human reproduction [7], and breast and prostate cancer [8,9]. Many animal findings have supported these human studies showing that BPA has effect at low doses around or below the reference dose (RfD). These animal studies include prostate and mammary tumors, advancement on puberty onset, obesity, fertility problems, and effect on behavior [10,11].

Exposure to BPA may irreversibly impact human health. Therefore it appears essential to assess the occupational exposure levels of plastic factory workers. The aim of this study has been to investigate for the first time the occupational exposure to BPA in plastic molding factory workers in Malaysia.

\section{MATERIAL AND METHODS}

\section{Workplace}

This study was done in a plastic factory. The main activity of the factory was the injection molding process using polycarbonate to produce a variety of products including household appliances and consumer electronics. The factory has 26 injection molding machines operating concurrently within the same work area over $24 \mathrm{~h}$ in 3 shifts.

The sampling exercise was carried out only at the injection molding unit therefore only workers operating on the injection molding machines were considered to be included in this study. The mode of operation of the machine is automatic and the workers are staying in front of the control interface station, this interface station allows the operator to control the machine's functions.

The injection molding is a process where plastic material is melted and then injected into the mold cavity. Once the melted plastic is in the mold, it cools to the desired shape. In this work the raw materials used are pellets of polycarbonate; approximately $80 \mathrm{t}$ of polycarbonate is used per shift. Bisphenol A is released during the extrusion process (converting the plastic pellets into melt and forcing it through a die which yields a desired shape). The extrusion tempereture was about $300^{\circ} \mathrm{C}$.

\section{Subjects and sampling}

We recruited 70 workers who had been working in the plastic factory from 3 months to 15 years, aged between 19 and 50 years old. Seventy non-exposed workers working in a research institute were selected as control subjects; they were of a similar age as those working in the plastic factory. This study was conducted according to the principles of the Declaration of Helsinki. All subjects were volunteers and provided their written informed consent.

Urine samples were collected from the 70 healthy volunteers and from the workers of the plastic molding factory at the end of their shifts. All samples were collected into $50 \mathrm{ml}$ beakers that had been baked at $420^{\circ} \mathrm{C}$ for $3 \mathrm{~h}$ and capped with aluminum sheet. The samples were then stored in $30 \mathrm{ml}$ glass bottles with aluminum caps at $-20^{\circ} \mathrm{C}$ until the analysis.

There are about 150 workers that are mainly operators in the factory. The temperature in the work area was measured by means of Wind Boy ISA- 80 Thermal Anemometer and recorded as $36.5^{\circ} \mathrm{C}$. Since a variety of resins are used in the factory the sampling exercise was carried out only at the injection molding unit work area where polycarbonate products were produced. The air sampling exercise was carried out for 2 shifts on the same day. The gas analyzers attached to XAD-2 

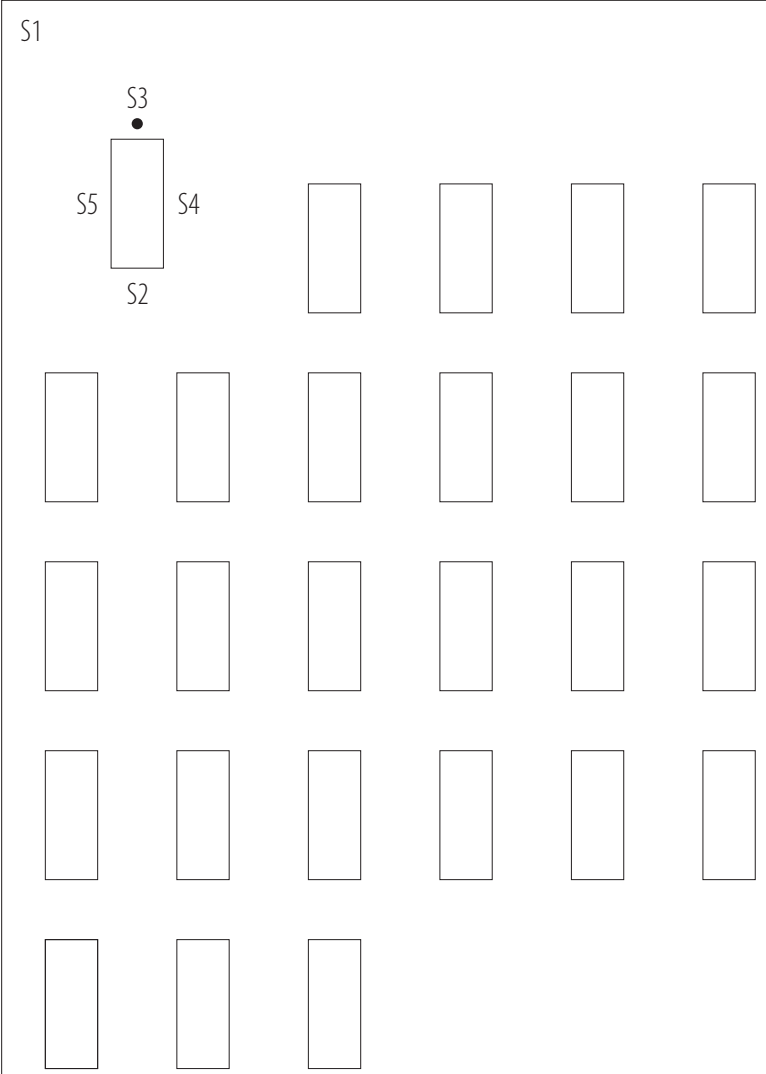

injection molding machines

- sitting point of the worker

$\$ 1$ - sampling point $1.5 \mathrm{~m}$ away from the molding machine.

S2 - sampling point at the collection of molded polycarbonate products.

S3 - sampling point at the staying position of the operator.

\$4 - sampling point at the right side of the machines.

S5 - sampling point at the left side of the machines.

Fig. 1. Floor plan of the plastic factory with sampling points to assess ambient bisphenol A (BPA), Malaysia

resin tubes were placed at $1.5 \mathrm{~m}$ above the ground at each sampling point of 5 molding machines to trap the air in the polycarbonate molding work area. The air was sampled for $8 \mathrm{~h}$ at $1 \mathrm{l} / \mathrm{min}$. The Figure 1 represents the sketching map of the floor plan of the molding factory.

Ambient air samples were collected from different sampling points in the research institute where the healthy control volunteers were working, comprising 28 buildings. The air samples collected within the compound of the research complex may be considered to be ambient air in a typical non-industrial area with no factories within $2.5 \mathrm{~km}$ radius. The temperature at the sampling sites was measured using Wind Boy ISA-80 Thermal Anemometer and recorded as $28^{\circ} \mathrm{C}$. Five gas analyzers attached to XAD-2 resin tubes in each sampling point were used for trapping the air. Air sampling was carried out for 6 at $1 \mathrm{l} / \mathrm{min}$.

\section{Chemicals and reagents}

Bisphenol A-d14 and bisphenol A were obtained from Wako Pure Chemicals Industries (Osaka, Japan). Bis(trimethylsilyl)tri-fluroacetamide (BSTFA) was obtained from Supelco (USA). Solvents used for extractions and reconstitutions, hexane, acetone, methanol and ethyl acetate were obtained from Fisher (UK) and were of high performance liquid chromatography (HPLC) grade. Anhydrous sodium sulfate was also obtained from Fisher Scientific UK. Beta-glucuronidase (G7646 Type V11-A) from Escherichia coli was obtained from Sigma-Aldrich (USA). Phosphate buffer $(1 \mathrm{ml}, 1 \mathrm{M})$ was prepared with bisphenol A free water.

\section{Air analysis}

The XAD-2 resin traps were cut into halves and extracted with $50 \mathrm{ml}$ solvent mixture of acetone:hexane (1:1) under ultrasonication for $15 \mathrm{~min}$. The solvent extracts were then concentrated to $3 \mathrm{ml}$ using a rotavapor. The concentrated solvents were transferred to $5 \mathrm{ml}$ amber vials and dried under the stream of nitrogen before derivatization. The internal standard $50 \mu \mathrm{l}$ of $1 \mathrm{mg} / \mathrm{l} \mathrm{bi}$ sphenol A-d14 was added to the vials. The extracts were then reacted with $100 \mu \mathrm{l}$ BSTFA. The derivatives were reconstituted to $1 \mathrm{ml}$ with solvent mixture ethyl acetate: hexane (1:4) and $1 \mu \mathrm{l}$ was injected to gas chromatographer mass spectrometer (GCMS). 
Gas chromatography mass spectrometry (GCMS) conditions

Quantification of BPA was performed using the Shimadzu gas chromatograph 17A coupled to a QP-5050A mass spectrometer under selected ion monitoring (SIM) mode using quadrupole detector. The GC column used for the purpose of the analysis was VB-1, manufactured by Valcobond, USA, of $15 \mathrm{~m}$ in length, internal diameter of $0.25 \mathrm{~mm}$ and thickness of $0.25 \mu \mathrm{m}$. The GCMS temperature programmed for the purpose of the analysis was as follows: initial temperature, $90^{\circ} \mathrm{C}$, ramp at $20^{\circ} \mathrm{C} / \mathrm{min}$ up to $100^{\circ} \mathrm{C}$, held for one min; followed by the second ramp at $10^{\circ} \mathrm{C} / \mathrm{min}$ up to $220^{\circ} \mathrm{C}$; and finally at $40^{\circ} \mathrm{C} / \mathrm{min}$ to $300^{\circ} \mathrm{C}$ and held for one min. Injector port temperature was set at $300^{\circ} \mathrm{C}$ while the interface temperature was set at $270^{\circ} \mathrm{C}$. Helium was used as the carrier gas. Quantification of the target analyte was based on the area ratio of the target analyte peak to the internal standard peak. The limit of detection (LOD) was $0.004 \mathrm{ng} / \mathrm{m}^{3}$ for bisphenol A and the limit of quantitation (LOQ) was $0.01 \mathrm{ng} / \mathrm{m}^{3}$. The spiked XAD-2 resin tubes were allowed to equilibrate for an hour, extracted and analyzed in the same manner as the air samples described earlier. Sample preparation was accompanied by at least one blank preparation to ensure blank control. Bisphenol A recovery was $90.4 \%$ and the coefficients of variation $(\mathrm{CV})$ were below 15 .

\section{Urine analysis}

Bisphenol A-glucuronide in the samples were cleaved enzymatically and both the conjugated bisphenol A (now as free bisphenol A) and the original free bisphenol A were extracted and analyzed as the total bisphenol A. Urine samples $(10 \mathrm{ml})$ were filtered through glass microfiber filters and spiked with surrogate standard bisphenol A-d14 (200 $\mu \mathrm{l}, 1 \mathrm{ng} / \mathrm{ml})$. The $\mathrm{pH}$ of the samples were adjusted to 6.8 by the addition of phosphate buffer $(1 \mathrm{ml}, 1 \mathrm{M})$ and incubated with $\beta$-glucuronidase (2500 units) overnight at $37^{\circ} \mathrm{C}$ in a water bath. The extraction procedure of BPA was performed by solid phase extraction (SPE). The SPE cartridges were conditioned with $6 \mathrm{ml}$ of acetone, hexane, ethyl acetate and bisphenol A free water and $10 \mathrm{ml}$ of urine sample was being loaded at a controlled flow of $1 \mathrm{ml} / \mathrm{min}$. After drying by vacuum pressure for $15 \mathrm{~min}$, final elution with $6 \mathrm{ml}$ ethyl acetate/ hexane (1:4 v/v) was applied to the SPE column. The SPE cartridge was dried with anhydrous sodium sulfate and the solvent fraction completely removed by a stream of nitrogen gas.

\section{GCMS conditions}

Quantification of BPA was performed by means of a Shimadzu QP-5050A gas chromatograph-mass spectrometer with quadrupole detector and analyzed in splitless and SIM mode. Derivatized bisphenol A ions monitored were 357 and 372 while retention time was $9.69 \mathrm{~min}$. For derivatized bisphenol A-d14, the ions monitored were 368 and 386 while retention time was $9.51 \mathrm{~min}$.

The GC column used was VB-1 (Valcobond, USA) (15 m length, I.D. $0.25 \mathrm{~mm}$ and $0.25 \mu \mathrm{m}$ thickness). The injection port was set at $310^{\circ} \mathrm{C}$ while the interface was set at $300^{\circ} \mathrm{C}$. Gas chromatography oven temperature program was as follows: Initial temperature, $120^{\circ} \mathrm{C}$, hold for $1 \mathrm{~min}$; then ramped at $40^{\circ} \mathrm{C} / \mathrm{min}$ to $184^{\circ} \mathrm{C}$, hold for $1 \mathrm{~min}$; and increased at $1^{\circ} \mathrm{C} / \mathrm{min}$ to $192^{\circ} \mathrm{C}$ and finally increased at $45^{\circ} \mathrm{C} / \mathrm{min}$ to $280^{\circ} \mathrm{C}$.

The limit of detection for bisphenol A analysis was $0.01 \mathrm{ng} / \mathrm{ml}$ while the limit of quantitation was $0.05 \mathrm{ng} / \mathrm{ml}$. The method developed was confirmed to be sufficiently precise, for the determination of trace amounts of bisphenol $\mathrm{A}$ in human urine.

The absolute recovery of bisphenol A was determined by direct comparison of peak areas from extracted vs. nonextracted samples. The mean recoveries for bisphenol A were $92.1 \%, 98.7 \%$ and $94.5 \%$ at $0.1,0.5$, and $0.9 \mathrm{ng} / \mathrm{ml}$ concentration. The coefficients of variances $(\mathrm{CVs})$ of bisphenol recovered for each of the concentration $(\mathrm{N}=5)$ were below $15 \%$. 


\section{Statistical analysis}

Air and urine BPA concentrations are presented as mean, median, and 25-75th percentile. Since the distribution of the data was not normal, we used the non-parametric Man-Whitney $U$ test for comparing between the medians. Spearman correlation was performed to examine the association between urinary BPA and air BPA among the studied population. To perform the correlation test we considered BPA concentrations at the staying position of the workers to be the individual exposure level. Spearman correlation test was chosen as the data was not in a normal bivariate distribution.

All analyses were performed using SPSS 20 (SPSS, Inc., Chicago, IL, USA). Significance was accepted at $\mathrm{p}<0.05$.

\section{RESULTS}

\section{Airborne BPA concentrations}

The sampling points in the factory were chosen to map out the distribution of BPA at different points around the injection molding machines (Table 1). Bisphenol A was detected in the median range of $8-28.3 \mathrm{ng} / \mathrm{m}^{3}$ for the 5 sampling points with the highest concentration detected at the collection of the finished polycarbonate products and the lowest concentration detected $1.5 \mathrm{~m}$ away from the machine. The $3 \mathrm{rd}$ sampling point corresponds to the staying position of the workers operating the machine and therefore may be considered to be the individual exposure level, the median BPA concentration at this position was $16 \mathrm{ng} / \mathrm{m}^{3}$.

In ambient air, BPA was detected in the median range of $2.4-3.59 \mathrm{ng} / \mathrm{m}^{3}$ for the 5 sampling points at the research institute (Table 2) with the highest concentration detected $0.5 \mathrm{~m}$ away from the ground and the lowest at the ground floor.

We compared the total BPA concentrations in the factory and the ambient air of the research institute (Table 3). The total median BPA concentration in the molding factory was 4 times higher than the median concentration detected in ambient air $(\mathrm{p}<0.001)$.

Table 1. Air bisphenol A (BPA) concentrations at different sampling points around the injection molding machine in the plastic factory, Malaysia

\begin{tabular}{|c|c|c|c|c|}
\hline \multirow[t]{2}{*}{ Sampling order and point } & \multirow{2}{*}{$\begin{array}{c}\text { Samples } \\
{[\mathrm{n}]}\end{array}$} & \multicolumn{3}{|c|}{$\begin{array}{c}\text { BPA concentration } \\
{\left[\mathrm{ng} / \mathrm{m}^{3}\right]}\end{array}$} \\
\hline & & $\mathrm{Me}$ & $\mathrm{M} \pm \mathrm{SD}$ & $25-75$ th percentile \\
\hline \multicolumn{5}{|l|}{$1 \mathrm{st}$} \\
\hline $1.5 \mathrm{~m}$ away from the molding machine & 5 & 8.00 & $8.50 \pm 2.95$ & $5.96-11.30$ \\
\hline \multicolumn{5}{|l|}{$2 \mathrm{nd}$} \\
\hline at the collection of molded polycarbonate products & 5 & 28.30 & $31.60 \pm 8.08$ & $25.40-39.60$ \\
\hline \multicolumn{5}{|l|}{$3 \mathrm{rd}$} \\
\hline staying position of the worker operator & 5 & 16.00 & $16.40 \pm 5.95$ & $11.59-21.53$ \\
\hline \multicolumn{5}{|l|}{4 th } \\
\hline $0.5 \mathrm{~m}$ to the right of the machine & 5 & 15.37 & $16.03 \pm 5.10$ & $11.26-21.12$ \\
\hline \multicolumn{5}{|l|}{5 th } \\
\hline $0.5 \mathrm{~m}$ to the left of the machine & 5 & 8.90 & $8.55 \pm 1.67$ & $6.87-10.05$ \\
\hline Total & 25 & 12.55 & $16.20 \pm 9.87$ & $9.17-22.50$ \\
\hline
\end{tabular}

Me - median; M - mean; SD - standard deviation. 
Table 2. Bisphenol A (BPA) concentrations in ambient air at different sampling points in the research institute, Malaysia

\begin{tabular}{|c|c|c|c|c|}
\hline \multirow[t]{2}{*}{ Sampling order and point } & \multirow{2}{*}{$\begin{array}{c}\text { Samples } \\
\text { [n] }\end{array}$} & \multicolumn{3}{|c|}{$\begin{array}{c}\text { BPA concentration } \\
{\left[\mathrm{ng} / \mathrm{m}^{3}\right]}\end{array}$} \\
\hline & & $\mathrm{Me}$ & $\mathrm{M} \pm \mathrm{SD}$ & $25-75$ th percentile \\
\hline \multicolumn{5}{|l|}{1 st } \\
\hline ground level & 5 & 2.40 & $2.38 \pm 1.35$ & $1.02-2.40$ \\
\hline \multicolumn{5}{|l|}{ 2nd } \\
\hline $0.5 \mathrm{~m}$ away from the ground & 5 & 4.00 & $3.59 \pm 1.87$ & $1.74-5.23$ \\
\hline \multicolumn{5}{|l|}{$3 \mathrm{rd}$} \\
\hline top of 2 buildings & 5 & 3.70 & $3.45 \pm 1.73$ & $1.83-4.94$ \\
\hline \multicolumn{5}{|l|}{ 4th } \\
\hline 5th level of a staircase & 5 & 3.50 & $3.58 \pm 1.62$ & $2.20-5.00$ \\
\hline \multicolumn{5}{|l|}{5 th } \\
\hline at a laboratory & 5 & 2.15 & $2.54 \pm 1.08$ & $1.60-3.67$ \\
\hline Total & 25 & 3.50 & $3.10 \pm 1.52$ & $1.60-4.20$ \\
\hline
\end{tabular}

Abbreviations as in Table 1.

Table 3. Comparison between bisphenol A (BPA) concentrations in the injection molding unit work area in the plastic factory and in ambient air, Malaysia

\begin{tabular}{lccc}
\hline \multirow{2}{*}{\multicolumn{1}{c}{ Samples source }} & \multicolumn{3}{c}{$\begin{array}{c}\text { BPA concentration* } \\
{\left[\mathrm{ng} / \mathrm{m}^{3}\right]}\end{array}$} \\
\cline { 2 - 4 } & $\mathrm{Me}$ & $\mathrm{M} \pm \mathrm{SD}$ & 25-75th percentile \\
\hline Plastic factory air & 12.55 & $16.20 \pm 9.87$ & $9.17-22.50$ \\
Ambient air (research institute air) & 3.50 & $3.10 \pm 1.52$ & $1.60-4.20$ \\
\hline
\end{tabular}

$* \mathrm{p}<0.001$.

Abbreviations as in Table 1.

Table 4. Concentration of bisphenol A (BPA) detected in $100 \%$ of urine samples for plastic factory workers and research institute workers, Malaysia

\begin{tabular}{lccc}
\hline \multirow{2}{*}{\multicolumn{1}{c}{ Respondents }} & \multicolumn{3}{c}{$\begin{array}{c}\text { BPA concentration* } \\
\text { [ng/ml }]\end{array}$} \\
\cline { 2 - 4 } & $\mathrm{Me}$ & $\mathrm{M} \pm \mathrm{SD}$ & 25-75th percentile \\
\hline Plastic factory workers - study group $(\mathrm{N}=70)$ & 3.81 & $3.88 \pm 2.65$ & $2.03-4.99$ \\
Research institute workers - control group $(\mathrm{N}=70)$ & 0.73 & $1.04 \pm 0.89$ & $0.33-1.57$ \\
\hline
\end{tabular}

$* \mathrm{p}<0.001$.

Abbreviations as in Table 1.

\section{Urinary BPA concentrations}

Descriptive statistics for BPA detected in urine samples of the factory workers and the control subjects are sum- marized in the Table 4. As in the airborne samples, urine BPA concentrations are significantly higher in the factory workers than in the control subjects $(\mathrm{p}<0.001)$. 


\section{Correlation between urinary BPA and air BPA}

We investigated the relationship between air BPA and urine BPA of the studied population. A significant correlation between the air BPA concentration and urine BPA concentration was found $(\varrho=0.55, \mathrm{p}<0.01)$.

\section{DISCUSSION}

In this study, we have shown that workers in the molding plastic factory who were exposed to BPA with a median airborne level of $12.5 \mathrm{ng} / \mathrm{m}^{3}$. The same workers who were occupationally-exposed to BPA showed a higher concentration of BPA in urine samples as compared to the control subjects working in the research institute.

Exposure to BPA in workplaces have been a public health concern in numerous countries, however reports differed from a factory to factory. In general studies on occupational exposure to BPA, epoxy resin workshops were investigated: the European study showed that the mean 8-h time weighted averages $\left(\right.$ TWA $_{8}$ ) of airborne BPA was $0.24 \mathrm{mg} / \mathrm{m}^{3}$ in epoxy resin plant and $7.9 \mathrm{mg} / \mathrm{m}^{3}$ in factories producing BPA [12]. These results are much higher than that of our polycarbonate molding factory, and this because the epoxy resin and BPA workshops are utilizing BPA as a primary material in high quantities. Another study in an electronic industry factory reported much lower mean values of airborne BPA $\left(8.8 \mathrm{ng} / \mathrm{m}^{3}\right)$. Only one study was similar to our conditions where they evaluated the organic compounds emitted during the molding process [13] They investigated several polycarbonate polymers blends but they couldn't detect bisphenol A in the air at the molding machine. This study is in contradiction with our study since we found a median concentration of $28.3 \mathrm{ng} / \mathrm{m}^{3}$ of BPA at the collection point of the molded products.

Our study showed that BPA concentration at the molding unit area $\left(12.5 \mathrm{ng} / \mathrm{m}^{3}\right)$ was much higher than in the ambient air $\left(3.5 \mathrm{ng} / \mathrm{m}^{3}\right)$. The urinary concentration in healthy Malaysian was $1 \mathrm{ng} / \mathrm{ml}$ [14], which was similar to our control subjects $(0.73 \mathrm{ng} / \mathrm{ml})$ and lesser than in the case of workers from the plastic factory $(3.81 \mathrm{ng} / \mathrm{ml})$. A study in epoxy resins factory in China showed that the median urinary levels of workers was $48 \mathrm{ng} / \mathrm{ml}$ [15], this was much higher than our findings, and might be explained by the fact that in our study the workers were sitting on the molding machine with only the chemical process enclosed in reaction pots, while raw BPA and epoxy resin were handled by workers in the epoxy resin factory. Although the urinary BPA concentrations for workers are low and the daily estimated intake seems lower than the reference dose of $50 \mu \mathrm{g} / \mathrm{kg}$ body weight (b.w.) per day, many animal studies have shown adverse effect much lower than the reference dose (RfD). Newbold et al. [16] have shown at a dose of 0.1 and $1 \mu \mathrm{g} / \mathrm{kg}$ b.w./day a disruption of female tract in mouse, Salian et al. [17] have shown adverse effect on the testis and spermatogenesis on 3 generation in rats after taking 1.2 and $2.4 \mu \mathrm{g} / \mathrm{kg}$ b.w./day of BPA, Matsuda et al. [18] have shown some changes in the brain of newborn rats exposed to bisphenol $\mathrm{A}$ at $0.1,1$ and $10 \mu \mathrm{g} / \mathrm{kg}$ b.w./day. These animal studies have clearly shown that BPA is able to induce adverse effects at doses that humans may encounter in their everyday lives and raise the question of the risks in polycarbonate molding factories where workers are exposed every day to the same small amounts of BPA.

\section{CONCLUSIONS}

To our knowledge this is the first study investigating the occupational exposure to BPA among workers in the molding polycarbonate factory in Malaysia. Given the growing public health concern about the possible impacts of low doses of BPA, it seems crucial to develop specific safety measures in order to protect the health of workers working on molding polycarbonate machines.

\section{ACKNOWLEDGMENTS}

The authors would like to thank Shimadzu Corporation, Japan, for providing technical help in the method development. 


\section{REFERENCES}

1. National Solid Waste Management Department. A study on plastic management in peninsular Malaysia - Final report. Putrajaya: The Department; 2011.

2. Rubin BS. Bisphenol A: An endocrine disruptor with widespread exposure and multiple effects. J Steroid Biochem Mol Biol. 2011;127(1-2):27-34, https://doi.org/10.1016/j.jsbmb.2011.05.002.

3. Watson CS, Jeng YJ, Guptarak J. Endocrine disruption via estrogen receptors that participate in nongenomic signaling pathways. J Steroid Biochem Mol Biol. 2011;127(1-2):44-50, https://doi.org/10.1016/j.jsbmb.2011.01.015.

4. Nakamura D, Yanagiba Y, Duan Z, Ito Y, Okamura A, Asaeda N, et al. Bisphenol A may cause testosterone reduction by adversely affecting both testis and pituitary systems similar to estradiol. Toxicol Lett. 2010;194(1-2):16-25, https://doi. org/10.1016/j.toxlet.2010.02.002.

5. Lang IA, Galloway TS, Scarlett A, Henley WE, Depledge M, Wallace RB, et al. Association of urinary bisphenol A concentration with medical disorders and laboratory abnormalities in adults. JAMA. 2008;300(11):1303-10, https://doi.org/10.10 01/jama.300.11.1303.

6. Miodovnik A, Engel SM, Zhu C, Ye X, Soorya LV, Silva MJ, et al. Endocrine disruptors and childhood social impairment. Neurotoxicology. 2011;32(2):261-7, https://doi.org/10.1016/ j.neuro.2010.12.009.

7. Tsutsumi O. Assessment of human contamination of estrogenic endocrine-disrupting chemicals and their risk for human reproduction. J Steroid Biochem Mol Biol. 2005;93 (2-5):325-30, https://doi.org/10.1016/j.jsbmb.2004.12.008.

8. Dong S, Terasaka S, Kiyama R. Bisphenol A induces a rapid activation of Erk1/2 through GPR30 in human breast cancer cells. Environ Pollut. 2011;159(1):212-8, https://doi.org/ 10.1016/j.envpol.2010.09.004.

9. Hess-Wilson JK. Bisphenol A may reduce the efficacy of androgen deprivation therapy in prostate cancer. Cancer Causes Control. 2009;20(7):1029-37, https://doi.org/10.1007/s10552-009-9337-8.
10. Vandenberg LN, Hauser R, Marcus M, Olea N, Welshons WV. Human exposure to bisphenol A (BPA). Reprod Toxicol. 2007;24(2):139-77, https://doi.org/10.1016/j.reprotox.2007.07.010.

11. Sekizawa J. Low-dose effects of bisphenol A: A serious threat to human health? J Toxicol Sci. 2008;33(4):389-403, https://doi.org/10.2131/jts.33.389.

12. European Commission. European Union risk assessment report: 4,4'-Isopropylidenediphenol (bisphenol-A). Ispra: The Commission; 2008.

13. Ligon WV, Maxam J, Grade H. Major organic volatiles evolved on moulding from the polymers: Lexan EM3110754, Lexan 920-80189, Lexan 103-112, Noryl PX1005X-701 and Noryl GTX 910-71653. Niskayuna: General Electric Research and Development Center; 1998.

14. Zhang Z, Alomirah H, Cho HS, Li YF, Liao C, Minh TB, et al. Urinary bisphenol A concentrations and their implications for human exposure in several Asian countries. Environ Sci Technol. 2011;45(16):7044-50, https://doi.org/10. 1021/es200976k.

15. Wang F, Hua J, Chen M, Xia Y, Zhang Q, Zhao R, et al. High urinary bisphenol A concentrations in workers and possible laboratory abnormalities. Occup Environ Med. 2012; 69(9):679-84, https://doi.org/10.1136/oemed-2011-100529.

16. Newbold RR, Jefferson WN, Padilla-Banks E. Prenatal exposure to bisphenol a at environmentally relevant doses adversely affects the murine female reproductive tract later in life. Environ Health Perspect. 2009;117(6):879-85, https:// doi.org/10.1289/ehp.0800045.

17. Salian S, Doshi T, Vanage G. Perinatal exposure of rats to Bisphenol A affects the fertility of male offspring. Life Sci. 2009; 85(21-2):742-52, https://doi.org/10.1016/j.lfs.2009.10.004.

18. Matsuda S, Saika S, Amano K, Shimizu E, Sajiki J. Changes in brain monoamine levels in neonatal rats exposed to bisphenol A at low doses. Chemosphere. 2010;78(7):894-906, https://doi.org/10.1016/j.chemosphere.2009.11.010.

This work is available in Open Access model and licensed under a Creative Commons Attribution-NonCommercial 3.0 Poland License - http://creativecommons.org/ licenses/by-nc/3.0/pl/deed.en. 